\title{
Inoculum Availability and Conidial Dispersal Patterns of Fusarium mangiferae, the Causal Agent of Mango Malformation Disease
}

\author{
E. Gamliel-Atinsky, A. Sztejnberg, M. Maymon, D. Shtienberg, and S. Freeman
}

First and second authors: Department of Plant Pathology and Microbiology, Faculty of Agricultural, Food and Environmental Quality Sciences; The Hebrew University of Jerusalem, P.O. Box 12, Rehovot, 76100; first, third, fourth, and fifth authors: Department of Plant Pathology and Weed Research, Agricultural Research Organization (ARO), the Volcani Center; P.O. Box 6, Bet Dagan, 50250, Israel. Accepted for publication 27 September 2008.

\begin{abstract}
Gamliel-Atinsky, E., Sztejnberg, A., Maymon, M., Shtienberg, D., and Freeman, S. 2009. Inoculum availability and conidial dispersal patterns of Fusarium mangiferae, the causal agent of mango malformation disease. Phytopathology 99:160-166.

Inoculum availability and conidial dispersal patterns of Fusarium mangiferae, causal agent of mango malformation disease, were studied during 2006 and 2007 in an experimental orchard. The spatial pattern of primary infections in a heavily infected commercial mango orchard corresponded with a typical dispersal pattern caused by airborne propagules. Malformed inflorescences were first observed in mid-March, gradually increased, reaching a peak in May, and declined to negligible levels in August. The sporulation capacity of the malformed inflores-

cences was evaluated during three consecutive months. Significantly higher numbers of conidia per gram of malformed inflorescence were detected in May and June than in April. Annual conidial dissemination patterns were evaluated by active and passive trapping of conidia. A peak in trapped airborne conidia was detected in May and June for both years. The daily pattern of conidial dispersal was not associated with a specifically discernable time of day, and an exponential correlation was determined between mean relative humidity $(\mathrm{RH})$ and mean number of trapped conidia. Higher numbers of conidia were trapped when RH values were low $(<55 \%)$. This is the first detailed report on airborne dispersal of F. mangiferae, serving as the primary means of inoculum spread.
\end{abstract}

Fusarium mangiferae Britz, M. J. Wingf. \& Marasas (previously recognized as $F$. moniliforme J. Sheld. and later as $F$. moniliforme J. Sheld. var. subglutinans Wollenw. \& Reinking), is the causal agent of mango malformation disease $(1,2,8,18$, $19,21,24,26,32,34)$. At least three additional taxa have been associated with the disease: F. sterilihyphosum Britz, Wingfield, \& Marasas from Brazil and South Africa, and Fusarium sp. nov. and F. proliferatum Samuels, Nirenberg \& Seifert (teleomorph: Gibberella intermedia) from Malaysia $(1,19)$. Mango malformation is prevalent in most mango-producing areas worldwide $(4,14,19,23)$. Because malformed inflorescences do not bear any fruit, malformation is a major constraint to mango production and high losses in yield are reported due to the disease from various mango-producing countries $(14,17,21,23,27,30)$. Symptoms of this disease are associated with hormonal imbalance in the host that results in tightly bunched, misshapen growth of vegetative leaves, shoots, and productive parts. Both vegetative shoots and axes of inflorescences are shorter, thicker, and highly branched. Inflorescences are compact and larger than normal, possess more male flowers, and hermaphroditic flowers that are formed are either sterile or eventually abort $(13,14,17,23,24,28)$.

The epidemiology of this disease is poorly understood $(14,23$, 24). The primary mechanism for long-distance dispersal of the pathogen is hypothesized to be via infected nursery stock or by the mango bud mite, Aceria mangiferae, vectoring fungal conidia. However, the method of pathogen dispersal within trees or spread from tree to tree in an infected orchard is unknown, although it is well documented that the disease spreads slowly within infected

Corresponding author: S. Freeman; E-mail address: freeman@volcani.agri.gov.il

doi:10.1094/PHYTO-99-2-0160

(c) 2009 The American Phytopathological Society orchards $(23,24)$. Single-celled microconidia are produced in abundance and carried on sympodially branched conidiophores bearing mono- and polyphialides, while macroconidia are usually three to five cells, borne on a sporodochia. No sexual stage is known for this species $(1,15)$. Ploetz $(23)$ indicated that aerial dissemination of conidia appears to be uncommon, based on a report that no conidia were trapped using rotary spore traps placed in an infected orchard (35). However, a study from Mexico reported the trapping of macroconidia in an infected mango orchard using a volumetric spore trap. In that study, identification of the pathogen was done microscopically for the genus level Fusarium spp. and only for macroconidia (21). Another study suggested that the conidia are the main source of inoculum, and also that the fungus "being a weak pathogen" invades the host via soft organelles (i.e., vegetative and floral buds, and flowers) (2). A study on the distribution of the pathogen in affected trees in Florida reported the highest colonization incidence in malformed vegetative and floral shoots, decreasing incidence in asymptomatic shoots, and rare colonization in branch tissue, even when the branch was supporting a malformed inflorescence (22). When whole infected seedlings were sectioned, pathogen colonization descended from the top to the lower sections (37). The latter study further demonstrated that survival of conidia declined very rapidly in soil and also that the pathogen was not detected in mango seed, seed coat, or flesh, implying that the pathogen is not seedborne. Ploetz (22) and Youssef (37) indicated that the pathogen is not a typical soilborne pathogen, nor does it move systemically from roots acropetally, and that mango buds are apparently the primary sites for infection. When malformation was managed in commercial orchards in Egypt by removing affected vegetative and floral terminals, the mean disease incidence was lower than in nonmanaged orchards (27). This management practice has also been used in India, Israel, and South Africa (23). 
Dispersal patterns of many foliar fungal pathogens are well documented, including several airborne Fusarium spp.; for example, $F$. circinatum, the causal agent of pine pitch canker $(3,9)$; $F$. graminearum, causal agent of Fusarium head blight of wheat $(6,11)$; and $F$. guttiforme (syn. F. subglutinans f. sp. ananas), causal agent of fusariosis in pineapple $(5,25)$. Detecting significant airborne conidia of $F$. mangiferae may support the hypothesis that conidia are the primary infection structures and shed light on better understanding the temporal and spatial patterns of $F$. mangiferae's conidia dispersal and their involvement in the epidemiology of malformation.

In this study, we detected a spatial pattern of primary infections in a heavily infected commercial orchard matching typical infection patterns caused by airborne propagules. This led us to postulate that the primary inoculum source in infected orchards is airborne conidia. The objectives of this study were to (i) determine the annual inoculum availability in infected orchards and (ii) study the annual and diurnal patterns of conidial dissemination.

\section{MATERIALS AND METHODS}

Spatial patterns of disease severity in a commercial orchard. Two commercial plots in Cholit, southern Israel, were assessed for disease severity during the 2005 flowering season. Plot 1, consisting of 48 20-year-old Tommy Atkins trees, was located $15 \mathrm{~m}$ from and adjacent to a heavily diseased orchard consisting of 26-year-old Keitt mango trees (inoculum source plot). Plot 2, consisting of 48 26-year-old mango trees cv. Keitt, was located further away from the diseased plot and continuous to plot 1 (Fig. 1). Both plots 1 and 2 were pruned heavily, 20 to $30 \mathrm{~cm}$ above the main trunks, using a chain saw in 2004. Malformed inflorescences were enumerated for each tree, three times during the season, on 8 and 12 March and 6 June and, following each disease assessment, malformed inflorescences were removed. A cumulative total value of disease severity was determined according to a scale of $<5,5$ to 15,15 to 25,25 to 35 , and $>35$ malformed inflorescences for each tree. A contour plot was drawn with the Contour Plot function in JMP software (ver. 5.0.1; SAS Institute Inc., Cary, NC) using the total malformed inflorescences per tree and the coordinates of each tree on the map. The cumulative values were also used to calculate the correlation of the distance from the inoculum source plot. Values were categorized to 3-m groups (the distance between neighboring trees) measured from the nearest point of the inoculum source plot. Averages and standard errors were calculated for each category, plotted, and analyzed using SigmaPlot 2001 software (SPSS, Chicago).

Annual inoculum availability. Inoculum presence was measured by counting the number of fresh malformed inflorescences from 10 trees growing in three parallel rows in the middle of a diseased plot located in the Volcani experimental mango orchard at Bet Dagan, consisting of 14 rows of trees with 10 trees per row. The trees consisted of a mixed cultivation of five mango cultivars-Keitt, Maya, Nimrod, Haden, and Palmer - all susceptible to $F$. mangiferae, representing the high disease severity of the orchard. Severity (i.e., the number of malformed inflorescences per tree) was determined starting from early March during both 2006 and 2007 and conducted at 3- to 4-week intervals until early September. Averages of malformed inflorescences per tree ( \pm standard error) were calculated.

Sporulation capacity of the malformed inflorescences (i.e., the number of conidia produced per $1 \mathrm{~g}$ of malformed inflorescence) was evaluated during three consecutive months (April, May, and June) of the flowering seasons of 2006 and 2007. Six malformed inflorescences ( 8 to $18 \mathrm{~cm}$ in length) were randomly sampled at each period from cv. Haden in the Volcani experimental orchard. One gram per sample was placed in $50 \mathrm{ml}$ of distilled sterilized water in Erlenmeyer flasks and shaken in a Lab-line orbit shaker (Lab Line Instruments Inc., Melrose Park, IL) for $1 \mathrm{~h}$ at $150 \mathrm{rpm}$. Inflorescence debris was filtered through a gauze pad and the liquid was centrifuged at $8,000 \mathrm{rpm}$ in a Hermle Z $400 \mathrm{~K}$ centrifuge (Hermle Labortechnik, Wehingen, Germany) for $10 \mathrm{~min}$. The pellet was suspended in $1 \mathrm{ml}$ of sterilized distilled water, transferred to 1.5-ml Eppendorf vials, and diluted 10- and 100-fold

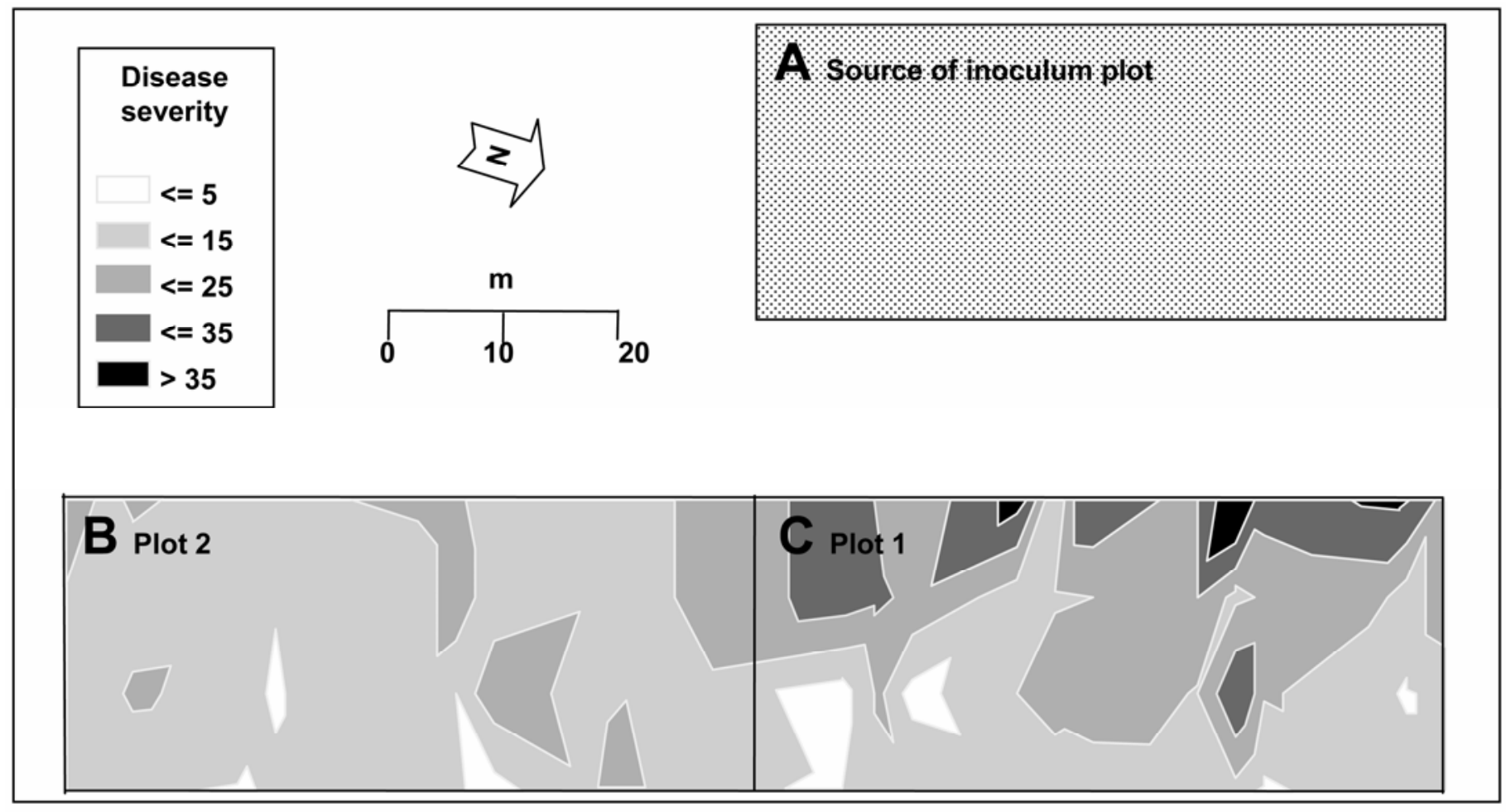

Fig. 1. Spatial pattern of mango malformation in two mango plots in Cholit commercial orchard, Southern Israel, during 2005. A, Inoculum source plot; B, number of malformed inflorescences per tree in plot no. 2 (cv. Keitt); C, number of malformed inflorescences per tree in plot no. 1 (cv. Tommy Atkins). 
and vortexed; then, $0.1 \mathrm{ml}$ from each dilution was plated on Nash selective media for Fusarium spp. isolation (20). Two plates per dilution were assessed for $F$. mangiferae after 5 days of incubation at $25 \pm 2{ }^{\circ} \mathrm{C}$. Identification of the fungus was carried out by microscopic observation and by specific polymerase chain reaction (PCR) primer amplification (38). The average number of conidia per gram of malformed inflorescence was calculated for each sampling date. Data were converted to log scale and analyzed using the Tukey-Kramer test. Data collected in each year were analyzed separately.

Annual pattern of conidial dissemination. The conidial dissemination pattern was evaluated by active and passive trapping of conidia in the Volcani experimental orchard during 2006 and 2007. Both active and passive traps were placed in the middle of the 10-tree plot described above. For the active trapping method, airborne conidia were monitored by sucking in air continuously at a speed of 10 liters/min on Burkard adhesive 'Melinex' clear tape, for periods of 7 days, using a Burkard volumetric spore trap (Burkard Scientific Sales Ltd., Rickmansworth, UK) which was placed $1 \mathrm{~m}$ above ground level. The adhesive tape was then cut into seven equal 1-day pieces and washed with $5 \mathrm{ml}$ of sterile water. Conidia were concentrated by centrifugation at 12,000 rpm in a Hermle Z $400 \mathrm{~K}$ centrifuge, and $1 \mathrm{ml}$ was plated on five plates containing Fusarium-selective medium for detection of $F$. mangiferae colonies. After washing, tapes were blotted on plates containing Fusarium-selective medium and removed from the plates the following day. Five days later, colonies were enumerated from all the plates and the pathogen was identified microscopically and verified by PCR using $F$. mangiferae-specific primers as described above. Data in 2006 were collected continuously from May until December, excluding 1 week in July, and the months of October through December, where only 1 week per month was sampled due to nil or very low presence of inoculum (airborne conidia). In 2007, the trap was operated 21 days in January, 6 days in February, and 14 days in March, then continuously from April through August, excluding 1 week in June and in July, and then 1 week in September, November, and December.

For the passive trapping method, 20 plates $90 \mathrm{~mm}$ in diameter containing Fusarium-selective medium were exposed in the orchard adjacent to the Burkard volumetric spore trap, by placing them at a height of $1.5 \mathrm{~m}$ above ground level. During 2006, plates were exposed once a month, and twice in the months of July and August. In 2007, plates were exposed once a month from February through November, and twice a month in March, April, June, July, and September. The lids of plates were removed at $1500 \mathrm{~h}$ for each exposure period and replaced at $0800 \mathrm{~h}$ of the

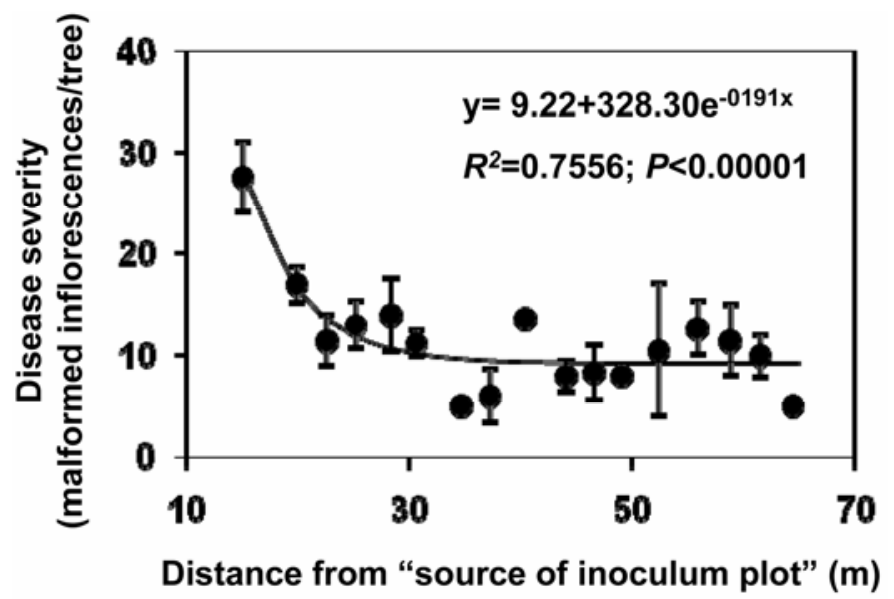

Fig. 2. Mango malformation severity calculated in respect to distance from an adjacent, heavily infected orchard (inoculum source plot). Vertical bars represent standard error of the mean. following morning. Subsequently, the plates were incubated in the laboratory and $F$. mangiferae was detected as previously described. Colony numbers representing numbers of trapped conidia of $F$. mangiferae per plate were calculated for each exposure period.

Diurnal patterns of conidial dissemination. In order to evaluate the daily pattern of conidial dispersal, the Burkard adhesive 'Melinex' clear tape was dissected into 3-h pieces during a 3 -week period in June 2007, and each piece was placed in a 1.5-ml Eppendorf vial containing $1 \mathrm{ml}$ of sterilized water, vortexed for $20 \mathrm{~s}$, and plated on Fusarium-selective medium as described above. Hourly measurements of relative humidity (RH) and temperature were recorded at a nearby $(0.5 \mathrm{~km})$ meteorological station by the Israeli meteorological service at Bet Dagan. Three-hour averages were calculated for both RH and temperature. In order to evaluate possible coincidence between $\mathrm{RH}$ and trapped conidia, data of conidia trapped during 3-h intervals and $\mathrm{RH}$ was divided into nine 5- $\mathrm{RH}$-unit groups from $\mathrm{RH}=50 \%$ to $\mathrm{RH}=95 \%$, and one relatively dry group of $40 \%<\mathrm{RH}<50 \%$. For each group, the average $\mathrm{RH}$ and the average trapped conidia were calculated. Data were analyzed using SigmaPlot 2001 software (SPSS).

\section{RESULTS}

Spatial patterns of disease severity in a commercial orchard. High numbers of infected inflorescences were detected in trees adjacent to the heavily malformed orchard in Cholit which presumably served as the inoculum source (Fig. 1A). Disease severity ranged from 0 to 25 malformed inflorescences per tree in plot 2 (Fig. 1B, cv. Keitt), which was lower than that in plot 1 (Fig. 1C, cv. Tommy Atkins). The latter was closer to the diseased orchard consisting of infected trees bearing $>60$ malformed inflorescences per tree. Within plot 1 , lower severity of the disease was detected in trees located further away from the diseased orchard. A decreasing exponential curve best described the coincidence between higher disease severity in trees and proximity to the inoculum source plot (Fig. 2).

Annual inoculum availability. Malformed inflorescences were first observed in the Volcani experimental orchard during midMarch in both years. The number of malformed inflorescences per tree increased gradually thereafter, reaching a peak in May, with an average of 30 and 84 malformed inflorescences per tree in 2006 and 2007, respectively. Disease severity declined to negligible levels in August (Fig. 3).

Overall, high numbers of conidia were obtained from malformed inflorescences, with sporulation capacity ranging from

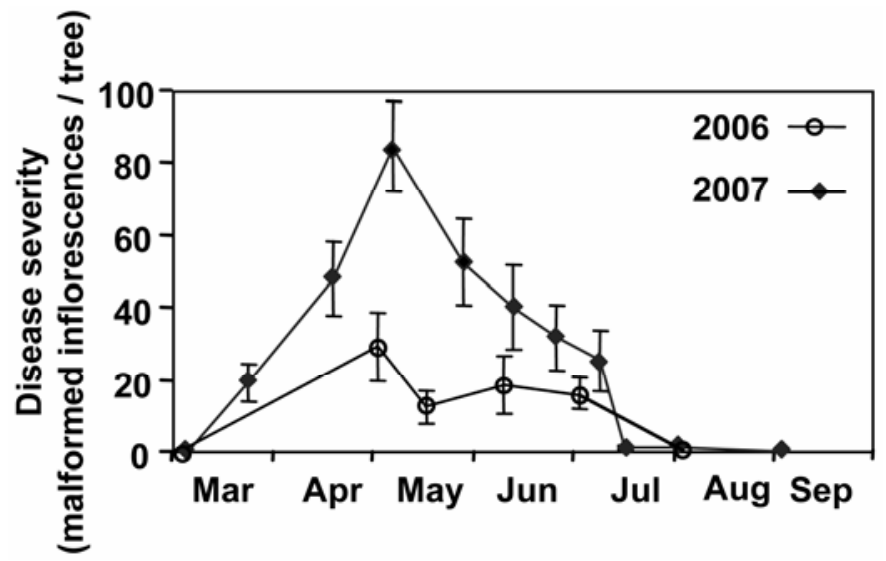

Fig. 3. Mango malformation severity in the Volcani experimental orchard during 2006 and 2007 at Bet Dagan, Israel. Data points represent averages for 10 trees from a mixture of cultivars. Vertical bars represent the standard error of the mean. 


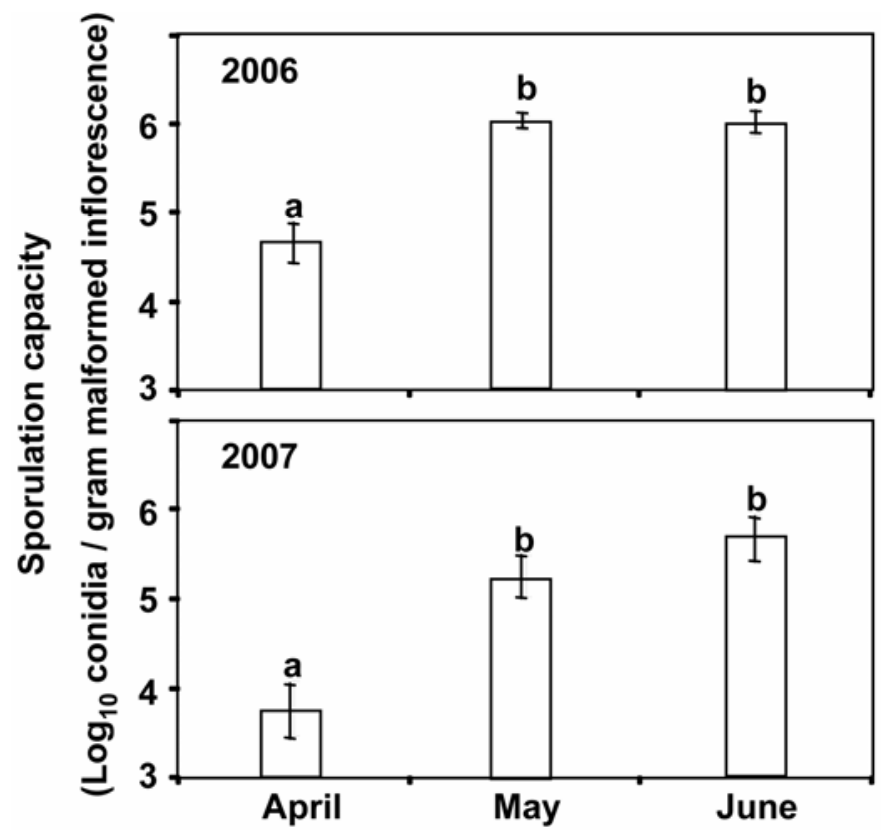

Fig. 4. Sporulation capacity of malformed inflorescences sampled from the Volcani experimental orchard over a 3-month period during 2006 and 2007. Vertical bars represent standard error of the mean (SE). Values were compared using Tukey-Kramer significant difference test for each year separately $(P<$ 0.0001 for 2006; $P=0.0003$ for 2007). Means with a common letter are not significantly different.
$5.9 \times 10^{3}$ conidia/g of malformed tissue sampled in April 2007 to a peak of $1 \times 10^{6}$ conidia/g of malformed tissue sampled in May 2006. Significantly $(P \leq 0.0003)$ more conidia per gram of malformed inflorescence were detected in May and June than in April during the 2 years of the survey (Fig. 4).

Annual pattern of conidial dissemination. A peak in trapped airborne conidia was detected in the Volcani experimental orchard, using the Burkard volumetric trap in May and June for both 2006 and 2007 (Fig. 5A). During this period, values of trapped conidia varied markedly from days with zero captures (e.g., 8 and 21 May 2006 and 4 May and 17 June 2007) to days with high numbers of trapped airborne conidia (e.g., 215, 62, 159, and 167 conidia trapped on 26 May and 9 June 2006 and 13 and 14 May 2007, respectively). During July through December in both years, low levels of conidia were trapped; in most days, no conidia were trapped and, for the remainder of the days, levels of 1 to 11 conidia were trapped per day.

In general, similar results were obtained using the selective medium for passive trapping of airborne conidia on plates in the orchard (Fig. 5B). Elevated levels of conidial dissemination were detected during April through July in 2006 and during May through July in 2007, with $4.6 \pm 0.25$, and $1.8 \pm 0.09$ average colonies per plate \pm standard error (SE), respectively. During the months January to March and August to December 2006 and February to April and August to November 2007, the number of conidia trapped in the petri plates was low, averaging $0.7 \pm 0.09$ colonies per plate in 2006 and $0.2 \pm 0.03$ in 2007 .

Diurnal patterns of conidial dissemination. The daily pattern of conidial dispersal did not relate to a specific discernable time of the day during the 21-day 3-h-trapping period. For example, on

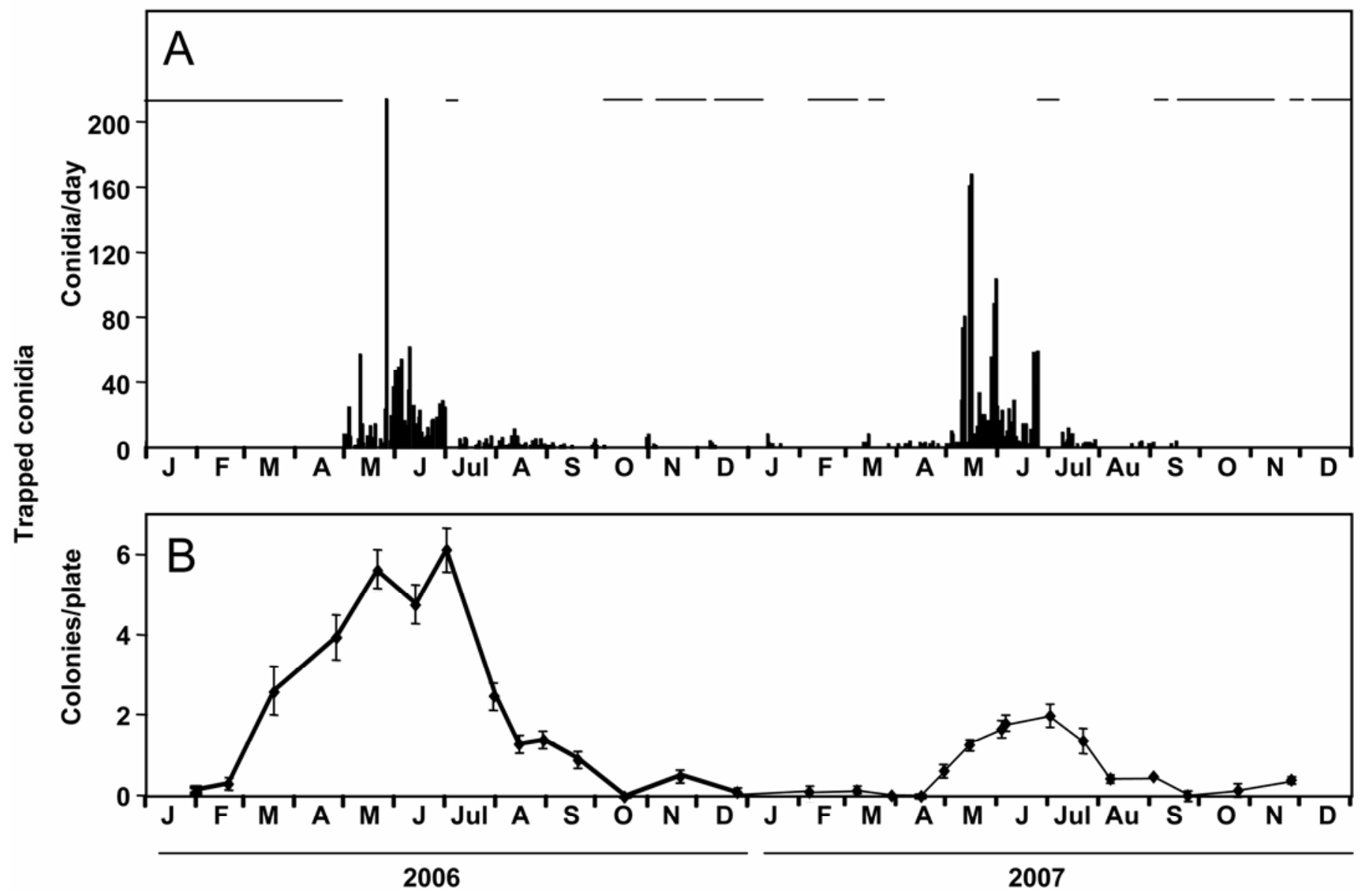

Fig. 5. Annual pattern of conidial trapping of Fusarium mangiferae in the Volcani experimental orchard during two consecutive years. A, Daily enumeration of conidia using the Burkard volumetric trap. The fragmented line represents nontrapping periods. B, Daily traps of conidia on plates containing Fusarium-selective medium exposed overnight from 1500 to $0800 \mathrm{~h}$ under orchard conditions. Bars represent standard error of the mean. 
21 June, between 2000 and $2300 \mathrm{~h}$, there was a daily dispersal peak of 20 conidia as opposed to a daily dispersal peak of 26 conidia on 23 June at the 1400 to 1700 h (Fig. 6). Daily peaks of eight dispersed conidia were also detected between 1100 to $1400 \mathrm{~h}$ on 9 June and between 0500 to $0800 \mathrm{~h}$ on June 10th (data not shown).

An exponential correlation was determined between mean RH and mean number of trapped conidia. Higher numbers of conidia were trapped when $\mathrm{RH}$ values were low, in particular below values of $55 \%$ (Fig. 7).

\section{DISCUSSION}

This is the first detailed report on $F$. mangiferae aerial dispersal of conidia. Abundant amounts of airborne conidia were detected in an infected orchard, suggesting that this is a significant means of spread of this fungus. In this study, inoculum availability was estimated by monitoring both formation and maturation of malformed inflorescences in an infected orchard, considered to be the main inoculum source $(2,27)$. An annual peak in malformed inflorescences was detected in May during a 2-year survey. Following and parallel to this peak, elevated levels of conidial dispersal were detected in May and June using both the active Burkard and passive plate-trapping methods during two consecutive years, apparently due to their release from mature malformed inflorescences.

Seasonal variations in conidial dispersal for other Fusarium spp. are a common phenomenon and were previously reported for several pathogens. Seasonal dynamics of airborne dispersal were demonstrated for $F$. graminearum macroconidia trapped in wheat plots using Burkard air samplers $(6,11)$, and also for $F$. crook- wellense, F. moniliforme, F. culmorum, F. sporotrichioides, F. equiseti, and $F$. subglutinans trapped within the same wheat plot (6). Seasonal fluctuation was also observed for $F$. circinatum airborne conidia trapped within forests in California $(3,9,31)$ and for $F$. guttiforme, causal agent of fusariosis in pineapple, showing a distinct high season for conidial dispersal starting in July through March and reaching a peak in January (5). A previous attempt to trap airborne conidia of Fusarium spp. in a heavily malformation-infected mango orchard using glass slides in rotary

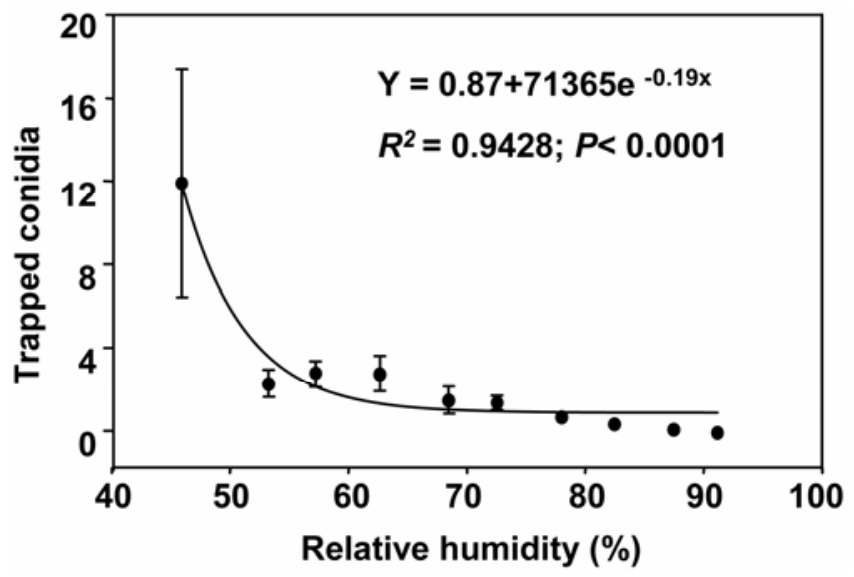

Fig. 7. Relationship between trapped conidia of Fusarium mangiferae and relative humidity $(\mathrm{RH})$. Conidia were trapped in the Volcani experimental orchard during June 2007 over a period of 3 weeks for every $3 \mathrm{~h}$. RH averages were calculated per each RH category of 5 units from 50 to $90 \%$, excluding the first category that included $10 \mathrm{RH}$ units from 40 to $50 \%$.
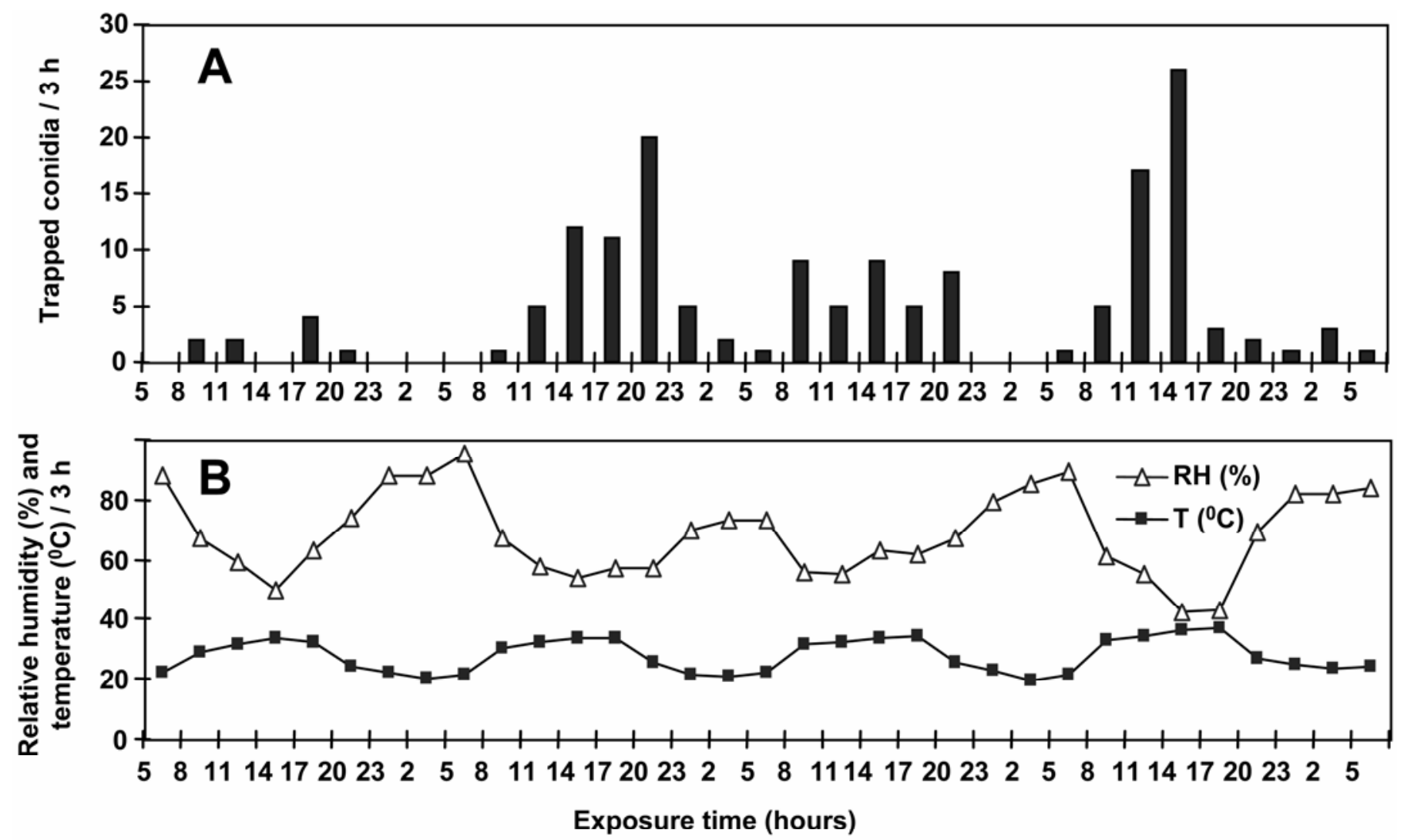

Jun-20-07

Jun-21-07

Jun-22-07

Jun-23-07

Fig. 6. Levels of diurnal trapped conidia of Fusarium mangiferae and relative humidity and temperature during the period of trapping. A, Diurnal pattern of trapped conidial during four consecutive days in June 2007 using a Burkard volumetric spore trap. B, Relative humidity $(\%)$ and temperature $\left({ }^{\circ} \mathrm{C}\right)$ data recorded during the trapping periods. 
spore traps failed (35), possibly due to the small size and lack of unique characteristics of conidia which made microscopic detection impossible. In our study, we successfully modified the traditional methodology of detecting Fusarium conidia using the Burkard sticky tape and, instead of counting propagules on the sticky tape under the microscope, we washed them off the tape, plated them on selective Fusarium medium, and identified colonies using both microscopic observation and specific PCR primer amplification. Our results contradict those of Inch et al. (11), who suggested that spores trapped in a Burkard 7-day spore trap cannot be plated and identified to the species level because they do not remain viable on the adhesive surface. Many studies have reported the active trapping of airborne Fusarium conidia, all of which utilized the technique of microscopic identification to detect pathogens from the trap. This technique, however, facilitated detection of conidia and larger-sized macroconidia only to the genus level $(6,11,21,29)$. In our study, diurnal dispersal of conidia was not associated with a specific time of day, similar to results from a previous study reporting sporadic conidial release of six Fusarium spp. sampled during 2 years in infected wheat plots in Canada (6). In our study, during June 2007, diurnal dispersal patterns of conidia of $F$. mangiferae correlated with lower levels of relative humidity, in particular, when relative humidity decreased below 55\% (Fig. 7). Similarly, Noriega-Cantú et al. (21) reported that a peak in trapped airborne macroconidia of Fusarium spp. was detected in infected mango orchards when relative humidity was low $(55 \%)$. This is also in agreement with the previously reported pattern of conidial dispersal of $F$. guttiforme, in pineapple, which coincided with relative humidity levels $<55 \%$ (5). Low relative humidity appears to be a major factor associated with the diurnal conidial dispersal of many airborne pathogens such as powdery mildews in vineyards (36), sweet cherry (10), apple (33), and other dry-dispersed fungal pathogens (7).

Three commercial mango plots were surveyed in this study for disease development during 2005. Two of the plots were heavily pruned in the previous year; therefore, we assumed that primary infections in those plots originated from the adjacent, highly infected plot which we considered the inoculum source plot. Indeed, a distinct pattern was detected which resembled a classic primary disease gradient where all infections are due to spores originating from an inoculum source (16). The disease gradient in both plots (Fig. 2) corresponded well with the disease gradient characteristics described by Madden et al. (16): "The disease shape is characterized by high disease intensity at and near the inoculum source, and generally declines with increasing distance from the source. The rate of the decline is usually large at small distances from the source, and small at large distances from the source." Plots 1 and 2 were located northeast and east from the inoculum source plot, respectively, which coincides with the common direction of the wind in this area at the time when relative humidity is low. Conidial dispersal by the wind appeared to cover a distance of up to $35 \mathrm{~m}$. Better understanding of plant pathogen dispersal characteristics may contribute to the ability to forecast disease development from early infections, assist in determining the optimal timing and means of control, and improve decision making for an optimal disease management program (12).

Our results have demonstrated that abundant amounts of $F$. mangiferae airborne conidia are dispersed in infected orchards and may serve as a significant source of primary inoculum. Thereof, it may be plausible to direct control efforts toward either reducing inoculum load or protecting trees from primary infections during the dissemination period.

\section{ACKNOWLEDGMENTS}

This research was supported in part by grant no. 132-0972 from the Chief Scientist of the Israeli Ministry of Agriculture, and by the Bureau for Economic Growth, Agriculture, and Trade, U.S. Agency for International Development, under the terms of the Middle East Regional Cooperation Program Award No. TA-MOU-02-M21-030, awarded to S. Freeman. We thank A. Zveibel, Y. Denisov, and M. Sharon for technical assistance.

\section{LITERATURE CITED}

1. Britz, H., Steenkamp, E. T., Coutinho, T. A., Wingfield, B. D., Marasas, W. F. O., and Wingfield, M. J. 2002. Two new species of Fusarium section Liseola associated with mango malformation. Mycologia 94:722730.

2. Chakrabarti, D. K., and Ghosal, S. 1989. The disease cycle of mango malformation induced by Fusarium moniliforme var. subglutinans and the curative effects of mangiferin-metal chelates. J. Phytopathol. 125:238246.

3. Correll, J. C., Gordon, T. R., McCain, A. H., Fox, J. W., Koehler, C. S., Wood, D. L., and Schultz, M. E. 1991. Pitch canker disease in California: Pathogenicity, distribution and canker development on Monterey pine (Pinus radiata). Plant Dis. 75:676-682.

4. Crookes, C. A., and Rijkenberg, F. H. J. 1985. A literature review of the distribution, symptomology, cause and control of mango blossom malformation. S. Afr. Mango Grow. Assoc. Res. Rep. 5:15-24.

5. De Matos, A. P., Sanches, N. F., and Costa, J. L. D. 1997. Patterns of diurnal and seasonal airborne spore concentrations of Fusarium subglutinans in a pineapple orchard in Brazil. Acta Hortic. 425:515-524.

6. Fernando, W. G. D., Miller, J. D., Seaman, W. L., Seifert, K., and Paulitz, T. A. 2000. Daily and seasonal dynamics of airborne spores of Fusarium graminearum and other Fusarium species sampled over wheat plots. Can. J. Bot. 78:497-505.

7. Fitt, B. D. L., McCartney, H. A. and Walklate, P. J. 1989. The role of rain in dispersal of pathogen inoculum. Annu. Rev. Phytopathol. 27:241270.

8. Freeman, S., Maimon, M., and Pinkas, Y. 1999. Use of GUS transformants of Fusarium subglutinans for determining aetiology of mango malformation disease. Phytopathology 89:456-461.

9. Garbelotto, M., Smith, T., and Schweigkofler, W. 2008. Variation of spore dispersal of Fusarium circinatum, the causal agent of pine pitch canker, over a 12-month-period at two locations in Northern California. Phytopathology 98:137-143.

10. Grove, G. G. 1998. Meteorological factors affecting airborne conidia concentrations and the latent period of Podosphaera clandestina on sweet cherry. Plant Dis. 82:741-746.

11. Inch, S., Fernando, W. G. D., and Gilbert, J. 2005. Seasonal and daily variation in the airborne concentration of Gibberella zeae (Schw.) Petch spores in Manitoba. Can. J. Plant Pathol. 27:357-363.

12. Jeger, M. J. 1999. Improved understanding of dispersal in crop pest and disease management: current status and future directions. Agric. For. Meteorol. 97:331-349.

13. Kumar, J., and Beniwal, S. P. S. 1992. Role of Fusarium species in the etiology of mango malformation. Page 17 in: Int. Mango Symp. Univ. Fla. IFAS, Tropical Research and Education Center, and International Society for Horticultural Science, Miami Beach, FL.

14. Kumar, J., Singh, U. S., and Beniwal, S. P. S. 1993. Mango malformation: one hundred years of research. Annu. Rev. Phytopathol. 31:217-232.

15. Leslie, J. F., and Summerell, B. A. 2006. The Fusarium Lab Manual. Blackwell, Ames, IA.

16. Madden, L. V., Hughes, G., and van den Bosch, F. 2007. The Study of Plant Disease Epidemics. American Phytopathological Society, St. Paul, MN.

17. Majumder, P. K., and Sinha, G. C. 1972. Studies on the effect of malformation on growth, sex ratio, fruit set and yield of mango. Acta Hortic. 24:230-234.

18. Manicom, B. Q. 1989. Blossom malformation of mango. S. Afr. Mango Grow. Assoc. Yearb. 10:11-12.

19. Marasas, W. F. O., Ploetz, R. C., Wingfield, M. J., Wingfield, B. D., and Steenkamp, E. T. 2006. Mango malformation disease and the associated Fusarium species. Phytopathology 96:667-672.

20. Nash, S. N., and Snyder, W. C. 1962. Quantitative estimations by plate counts of propagules of the bean rot Fusarium in field soils. Phytopathology 73:458-462.

21. Noriega-Cantú, D. H., Téliz, D., Mora-Aguilera, G., Rodriguez-Alcazar, J., Zavaleta Mejía, E., Otero-Colinas, G., and Campbell, C. L. 1999. Epidemiology of mango malformation in Guerrero, Mexico, with traditional and integrated management. Plant Dis. 83:223-228.

22. Ploetz, R. C. 1994. Distribution and prevalence of Fusarium subglutinans in mango trees affected by malformation. Can. J. Bot. 72:7-9.

23. Ploetz, R. C. 2001. Malformation: a unique and important disease of mango, Mangifera indica L. Pages 233-247 in: Fusarium: Paul E. Nelson 
Memorial Symposium. B. A. Summerell, J. F. Leslie, D. Backhouse, W. L. Bryden, and W. L. Burgess. eds. American Phytopathological Society, St. Paul, MN.

24. Ploetz, R. C. 2003. Diseases of mango. Pages 327-363 in: Diseases of Tropical Fruit Crops. R. C. Ploetz, ed. CABI Publishing, Oxford, UK.

25. Ploetz, R. C. 2006. Fusarium-induced diseases of tropical, perennial crops. Phytopathology 96:648-652.

26. Ploetz, R. C., and Gregory, N. 1993. Mango malformation in Florida: Distribution of Fusarium subglutinans in affected trees, and relationships within and among strains from different orchards. Acta Hortic. 341:388394.

27. Ploetz, R., Zheng, Q. I., Vazquez, A., and Abdel Sattar, M. A. 2002. Current status and impact of mango malformation in Egypt. Int. J. Pest Manage. 48:279-285.

28. Prasad, A., Singh, N., and Singh, S. 1972. Mango malformation-a review of work done at the horticultural research institute, Saharanpur, India. Acta Hortic. 24:227-229.

29. Rossi, V., Languasco, L., Pattori, E., and Giosuè, S. 2002. Dynamics of airborne Fusarium macroconidia in wheat fields naturally affected by head blight. J. Plant Pathol. 84:53-64.

30. Sao Jose, A. R., Souza, S. E., Vega Pina, A., and Ataide, E. M. 2000. Incidence and severity of mango flower malformation in Bahia State, Brazil. Acta Hortic. 509:765-767.

31. Schweigkofler, W., O'Donnell, K., and Garbelotto, M. Detection and quantification of airborne conidia of Fusarium circinatum, the causal agent of pine pitch canker, from two California sites by using a real-time PCR approach combined with a simple spore trapping method. Appl. Environ. Microbiol. 70:3512-3520.

32. Summanwar, A. S., Raychaudhuri, S. P., and Phatak, S. C. 1966. Association of the fungus Fusarium moniliforme Sheld. with the malformation in mango (Mangifera indica L.). Indian Phytopathol. 19:227-228.

33. Sutton, T. B., and Jones, A. L. 1979. Analysis of factors affecting dispersal of apple powdery mildew caused by Podosphaera leucotricha conidia. Phytopathology 69:380-383.

34. Varma, A., Lele, V. C., Raychoudhuri, S. P., Ram, A., and Sang, A. 1974. Mango malformation: a fungal disease. Phytopathol. Z. 79:254-257.

35. Varma, A., Raychaldhuri, S. P. Lele, V. C., and Ram, A. 1971. Preliminary investigations on epidemiology and control of mango malformation. Proc. Indian Nat. Sci. Acad. 37:291-300.

36. Willocquet, L., and Clerjeau, M. 1998. An analysis of the effects of environmental factors on conidial dispersal of Uncinula necator (grape powdery mildew) in vineyards. Plant Pathol. 47:227-233.

37. Youssef, S. A., Maymon, M., Zveibil, A., Klein-Gueta, D., Sztejnberg, A., Shalaby, A. A., and Freeman, S. 2007. Epidemiological aspects of mango malformation disease caused by Fusarium mangiferae and source of infection in seedlings cultivated in orchards in Egypt. Plant Pathol. 56:257-263

38. Zheng, Q., and Ploetz, R. 2002. Genetic diversity in the mango malformation pathogen and development of a PCR assay. Plant Pathol. 51:208-216. 